\title{
Receiving a toluelenediisocyanate with use bis(trichloromethyl)carbonate
}

\author{
(C) Yulia Yu. Golubeva, ${ }^{+}$Lyudmila A. Sokhadze, ${ }^{*}$ Vitaly V. Turygin, \\ Pavel V. Kazakov, and Irina D. Derevyagina \\ Federal State Unitary Enterprise "State Research Institute of Organic Chemistry and Technology" \\ State Scientific Center of the Russian Federation. Entuziastov Ave., 23. Moscow, 111024. Russia. \\ Phone:+7 (495)673-75-30.E-mail:dir@gosniiokht.ru
}

*Supervising author; ${ }^{+}$Corresponding author Keywords: aryldiisocyanate, bis(trichlormethyl)carbonate, tolyulendiamine, tolyulendiisocyanate, carbonylchloride.

\begin{abstract}
Toluelenediisocyanate - large-capacity reagent with a wide scope. The main quantity $(85 \%$ of world production) of a toluelenediisocyanate is used for receiving polyurethane foam.

The main way of receiving a toluelenediisocyanate is interaction of a toluelenediamine with carbonylchloride. If in the industry use of carbonylchloride as carbonylating agents have no difficulties, then in laboratory they exist. Carbonylchloride is inaccessible in the market. Usually it is received at the same enterprises at which further use.

Now, as alternative and commercially available carbonylating agents, use bis(trichlormethyl)carbonate. Bis(trichlormethyl)carbonate a possibility of use in synthesis of aryldiisocyanates is directly connected with its physical properties, bis(trichlormethyl)carbonate represents steady crystal connection. Therefore its use in reaction of carbonylation of amines is more convenient, than gaseous carbonylchloride.

There was a need for definition of optimum conditions of carrying out process of receiving this aryldiisocyanate with a satisfactory exit, because of inconsistency of references.

For achievement of goals of a research - receiving a toluelenediisocyanate with use the bis(trichlormethyl)carbonate - we defined conditions of solubility of a toluelenediamine and the bis(trichlormethyl)carbonate in benzenechloride, influence of their molar ratio on an aryldiisocyanate exit is studied, also need of use of surplus is proved the bis(trichlormethyl)carbonate for suppression of course of collateral reactions.

The offered method allows carrying out reaction to one stage, also to refuse low temperature at a stage of introduction of amine and it is essential to reduce synthesis time. conditions.

This method can be used both in laboratory practice and in the production of isocyanates in industrial
\end{abstract}

\section{References}

[1] M.F. Sonnenschein. Polyurethanes. Science, technology, markets and trends. USA: Willey. 2018. 576p.

[2] V.I. Gorbatenko, E.Z. Zhuravlev, L.I. Samara. Isocyanates. Methods of synthesis and physical and chemical properties alkyl-, aril- and geterilizotsianat. Kiev: Naukova Dumka. 1987. 446p.

[3] Y. Wang, X. Zhao, F. Li, S. Wang, J. Zhang. Catalytic synthesis of toluelene-2.4-diisocyanate from dimethyl carbonate. J. Chem. tech. biotech. 2001. Vol.76. P.857-861.

[4] S. Brase, K. Banet. Organic Azides: Syntheses and applications. John Wiley \& Sons, Ltd, Chichester. 2010. 322p.

[5] L. Cotarca, H. Eckert. Phosgenations - a handbook. W.: Wiley-VCH. 2003. 670p.

[6] H. Eckert, B. Forster. Triphosgene, a crystalline phosgene substitute. J. Angew. Chem. 1987. Vol.99. P.922-934.

[7] H. Eckert. Use of bistrichloromethyl carbonate as a proreagent for phosgene. Patent DE 3440441. 1984.

[8] A.H. Telli. Synthesis and characterization of toluene diisocyanate. Moscow: Thesis of the master of chemical sciences. 2014. 66p.

[9] L. Cotarca, R. Bacaloglu, C. Csunderlik, N. Marcu, A. Tarnaveanu. Aminolyse des bis(trichlormethyl)carbonates. J. f. prakt. Chemie.Band. 1987. Vol.6. P.1052-1062. 